\title{
BRITISH MUSEUM NATURAL RADIOCARBON MEASUREMENTS II
}

\author{
H. BARKER and C. J. MACKEY
}

\author{
Research Laboratory, British Museum, London W.C.1.
}

The second series of radiocarbon measurements made at the British $\mathrm{Mu}$ seum Research Laboratory are reported in the following list. The equipment and method used remain the same as described in our first date list (Barker and Mackey, 1959) and, as stated there, the error terms are not based solely on counting statistics but are widened to include contributions of \pm 80 years for possible isotopic fractionation effects and \pm 100 years for the de Vrieseffect. Ages are calculated on a half-life of $5568 \pm 30$ years.

\section{PRETREATMENT OF SAMPLES}

Some slight modifications have been made in our procedure since the publication of the first list. The standard pretreatment for charcoal remains essentially the same, i.e., thorough extraction, first, with hot $1 \%$ hydrochloric acid (usually three separate extractions), followed by a similarly thorough treatment with hot $1 \%$ caustic soda. Some so-called charcoals are found to be so soluble in caustic soda that they dissolve completely under this treatment; in these cases a modified treatment has been adopted which is noted in the text.

Wood is now given one extraction with hot $1 \%$ caustic soda aimed at eliminating, at least in part, any possible humic contamination. This procedure follows the usual thorough extraction with hot $1 \%$ hydrochloric acid to remove carbonates. In all cases where alkaline extraction is employed, the sample is re-washed with dilute hydrochloric acid and then with distilled water before drying.

\section{ACKNOWLEDGMENT}

Thanks are due to the Director and staff members, Atomic Energy Research Establishment, Harwell, for continued help in electronic servicing.

\section{SAMPLE DESCRIPTIONS}

\section{ARCHAEOLOGIC SAMPLES}

\section{A. Africa}

\section{BM-52. Galla Graves, Somaliland Protectorate}

$100 \pm 150$

Wood found at ground level at the bottom of a mound burial of a type of grave attributed to pre-Somali inhabitants of Somaliland (The Galla). Precise location: Gaan Nibaah ( $9^{\circ} 52^{\prime} \mathrm{N}$ Lat, $44^{\circ} 48^{\prime}$ E Long), Somaliland Protectorate. Coll. April 1957 and subm. by I. M. Lewis, University College of Rhodesia and Nyasaland. There are no other comparative dates, and this one would seem to imply that the grave is recent and probably Somali rather than Galla. Relevant publications-Lewis, in press $(\mathrm{a}, \mathrm{b})$. Comment: sample was given standard pretreatment for wood. 


\section{BM-57. Amadzimba Cave, Southern Rhodesia}

$4200 \pm 150$

Carbonized bone and wood ash (charcoal) from the lower half of the Wilton deposit, at 6 to 12 in. depth, squares Ce and Cf, at Amadzimba Cave, South Matopos (20 45' S Lat, $28^{\circ} 45^{\prime} \mathrm{E}$ Long), Southern Rhodesia. Coll. September 21, 1954 by K. R. Robinson, Commission for the Preservation of Natural and Historical Monuments and Relics, Bulawayo; subm. by K. P. Oakley, British Museum (Natural History). Relevant publications-Robinson and Cooke, 1950, 1954. Comment: sample was given the standard pretreatment for charcoal.

\section{BM-67. Rio Frio, Cayo District}

$1120 \pm 150$

Charred wood from a small cave or recess $33 \mathrm{ft}$ above the main cave floor in the west side wall of Rio Frio Far Cave $\left(16^{\circ} 58^{\prime} 15^{\prime \prime} \mathrm{N}\right.$ Lat, $88^{\circ} 58^{\prime} 45^{\prime \prime} \mathrm{W}$ Long), Cayo District, British Honduras, about $2 \mathrm{mi} \mathrm{SW}$ of Augustine Forest Department Headquarters on a mountain pine ridge, altitude $1600 \mathrm{ft}$ above sealevel. Sample was buried under a heavy deposit of desiccated bat manure and bones, and was in association with Mayan pottery and artifacts. Coll. January 1959 by A. H. Anderson, Archaeological Commissioner, British Honduras; subm. by Adrian Digby, Keeper of the Department of Ethnography, British Museum. Comment: sample was given the standard pretreatment for charcoal.

\section{BM-56. Mycerinus, Gizeh}

$$
\text { C. Egypt }
$$

$1500 \pm 150$

Human skin from the body of a man (now in the British Museum) found by H. Raven when working for Col. Howard Vyse in 1838 in the Pyramid of Mycerinus, Gizeh $\left(29^{\circ} 58^{\prime} \mathrm{N}\right.$ Lat, $31^{\circ} 07^{\prime} 30^{\prime \prime} \mathrm{E}$ Long), Egypt. Subm. by I. E. S. Edwards, Keeper of the Department of Egyptian Antiquities, British Museum. Relevant publication-Vyse, 1841, p. 86. The result disposes of the suggestion that the body is that of King Mycerinus which had been placed in a new coffin about 600 B.c. Comment: pretreatment: skin was steeped in cold $1 \%$ hydrochloric acid overnight, washed with cold water, and dried.

\section{Great Britain}

BM-46. Stonehenge, Wiltshire

Red deer antler found at the base of the clean chalk filling of the ramp leading to Stonehole 56 of the Great Trilithon at Stonehenge, Wiltshire $\left(51^{\circ}\right.$ $41^{\prime} 45^{\prime \prime} \mathrm{N}$ Lat, $1^{\circ} 49^{\prime} 30^{\prime \prime} \mathrm{W}$ Long). Coll. April 1958 and subm. by Stuart Piggott, University of Edinburgh. The excavation was done under the auspices of the Ministry of Works. Comment: on archaeologic grounds, the expected date is in the region of 1600-1550 B.c. Pretreatment: antler was heavily mineralized and was therefore milled to a coarse powder and extracted with cold $1 \%$ hydrochloric acid in order to remove carbonates. The organic fraction was largely unaffected by this treatment and was separated, washed with cold water, and dried.

BM-47. Hod Hill, Dorset

$2410 \pm 150$

Charcoal from an occupation layer $3.25 \mathrm{mi} \mathrm{NW}$ of Blandford, Dorset $\left(50^{\circ}\right.$ 
$53^{\prime} 40^{\prime \prime} \mathrm{N}$ Lat, $2^{\circ} 12^{\prime} \mathrm{W}$ Long), associated with stage II (?) of the main Iron Age rampart and Iron Age "AB" pottery. Coll. 1958 by J. W. Brailsford, Department of British and Medieval Antiquities, British Museum; subm. by that Department. Comment: a sample taken in 1957 from the same site gave an age of $1570 \pm 150$ (BM-17, Barker and Mackey, 1959). This was some centuries younger than the latest accepted archaeologic dating. The discrepancy could have been due to sample contamination, for there was some evidence of rootlet penetration. This new sample was very carefully selected, in the laboratory, from a large quantity of the occupation layer, and every effort was made to select only fragments of charcoal which showed no signs of rootlet penetration. Sample was then given standard pretreatment for charcoal.

BM-49. Nutbane, Long Barrow, Hampshire $\quad 4680 \pm 150$

Charcoal from the post holes of the second forecourt building in an earthen long barrow at Nutbane, Penton Mewsey near Andover, Hampshire $\left(51^{\circ} 12^{\prime}\right.$ $30^{\prime \prime} \mathrm{N}$ Lat, $1^{\circ} 28^{\prime} \mathrm{W}$ Long). National Grid ref: S U 330495. This building was purposely burnt when the barrow mound was thrown up to cover the structures in the final phase of construction. Charcoal forming the remains of the posts was obtained from post trenches, up to $4.5 \mathrm{ft}$ in depth. Coll. AugustOctober 1957 and subm. by Faith de Mallet Vatcher (née Morgan). The excavation was done under the auspices of the Ministry of Works. Relevant publication-Morgan and Ashbee, 1958. Comment: sample was given standard pretreatment for charcoal.

BM-58. Ferriby Boats, Yorkshire

$2700 \pm 150$

Prehistoric boats of an unusual "sewn" construction were found on a site near low-water mark on the $\mathrm{N}$ shore of the Humber estuary at North Ferriby, Yorkshire $\left(53^{\circ} 42^{\prime} 48^{\prime \prime}\right.$ N Lat, $0^{\circ} 29^{\prime} 52^{\prime \prime}$ E Long). Sample is from wooden sealing strip (oak) found in the gray clay approximately 3 yd south of Boat $\mathrm{I}$. The area contained numerous fragments of sealing strip, caulking moss, and scraps of rope associated with the boat. Coll. 1954 and subm. by E. V. Wright of Freshfield, Elloughton-Brough, Yorkshire. Relevant publication-Wright and Wright, 1947. Comment: sample was given the standard pretreatment for wood.

BM-62. Antofts Windypit, Helmsley, Yorkshire $\quad 3750 \pm 150$

Sample of charcoal from a hearth $80 \mathrm{ft}$ down from the surface in a fissure known as Antofts Windypit at Helmsley, Yorkshire (54 $14^{\prime} \mathrm{N}$ Lat, $1^{\circ} 6^{\prime} 4^{\prime \prime} \mathrm{W}$ Long). National Grid ref: 583829-6-in. Ordnance Survey Y.N.R. Sheet 58 S.E. The hearth was in association with "B" beaker pottery and burials, and the associated finds are now in the Scarborough Museum. Found May 1955 by R. H. Hayes and party. Comment: date is consistent with the archaeologically accepted age of the pottery. Sample was given standard pretreatment for charcoal.

BM-63. Staple Howe, East Yorkshire

$2400 \pm 150$

Charred grain from an early Iron Age "A" settlement at Staple Howe, Knapton, East Yorkshire $\left(50^{\circ} 10^{\prime} \mathrm{N}\right.$ Lat, $0^{\circ} 40^{\prime} \mathrm{W}$ Long). Coll. 1958 by T. C. M. Brewster; subm. by the Department of British and Medieval Antiquities, British Museum. Comment: the archaeologic evidence points to a short 
period of occupation, and the date agrees well with that based on archaeologic considerations. Sample was given the standard pretreatment for charcoal.

\section{BM-65. Thatcham, Berkshire}

$8100 \pm 180$

Charcoal from Site 2, layer 2, of an excavation at the Mesolithic site, at Thatcham Sewage Works, Thatcham, near Newbury, Berkshire (51 $23^{\prime} 30^{\prime \prime}$ N Lat, $1^{\circ} 16^{\prime} 52^{\prime \prime}$ W Long). National Grid ref: 502668. Coll. 1958 and subm. by John Wymer, Assistant Curator, Reading Museum. Relevant publicationWymer, 1959. Analysis of the associated pollen by W. G. Dimbleby, Oxford University, places the sample in the Early Atlantic zone. Comment: the site may be Classic Maglemose. An early Maglemose date for England is C-353, $9488 \pm 350$ (Libby, 1955, p. 88). Sample showed indications of rootlet penetration and was very carefully sorted in order to eliminate this as far as possible. It was not a hard charcoal and was soluble in caustic soda so that chemical pretreatment had to be restricted to extraction with hot $1 \%$ hydrochloric acid.

$$
\text { E. India }
$$

BM-54. Utnur

$4120 \pm 150$

Charcoal from the first occupation deposit of a Deccan Neolithic ash mound at Utnur ( $16^{\circ} 0^{\prime} 40^{\prime \prime} \mathrm{N}$ Lat, $77^{\circ} 38^{\prime} \mathrm{E}$ Long), India. Coll. August 1957 by F. R. Allchin and P. Srinivasachar; subm. by F. R. Allchin, School of Oriental and African Studies, University of London. A report on the excavation will appear in a future issue of Andhra Pradesh Archaeological Series, Hyderabad, Deccan. No previous dates are available for this region of culture, but cross-dating suggests that it is earlier than the Navdatoli Chalcolithic (Sankalia, 1958).

\section{F. Malaya}

BM-43. Cave Gua Harriman

$3450 \pm 150$

Charcoal from a hearth containing Neolithic cord-impressed pots, in Gua Harriman, a small cave in Gunong Dayak $\left(5^{\circ} 9^{\prime} \mathrm{N}\right.$ Lat, $100^{\circ} 5^{\prime} 30^{\prime \prime} \mathrm{E}$ Long), Malaya 1" series Sheet 2-1/16 D 763377. Coll. 1951 and subm. by the late Major P. D. R. Williams-Hunt. Relevant publications-Williams-Hunt, 1952; Tweedie, 1953. Comment: sample was given standard pretreatment for charcoal.

\section{G. Siam (Thailand)}

\section{BM-41. Muang Phet}

$1810 \pm 150$

Charcoal from a depth of $4 \mathrm{ft}$ in layer II of an excavation of an "early historic" period site at Muang Phet (15 N Lat, $102^{\circ} 35^{\prime} \mathrm{E}$ Long), Eastern Siam (Thailand). Coll. December 1955 and subm. by H. G. Quaritch-Wales. Relevant publication-Quaritch-Wales, 1957. Comment: sample was given standard pretreatment for charcoal.

\section{H. Turkey}

BM-48. Hacilar

$7550 \pm 180$

Charcoal asociated with the burning of level VI, area B at Hacilar, $25 \mathrm{~km}$

$\mathrm{W}$ of Burdar, SW Anatolia (37 $35^{\prime} \mathrm{N}$ Lat, $30^{\circ} 5^{\prime} \mathrm{E}$ Long), Turkey. Coll. 
September 1957 by James Mellaart, British Institute of Archaeology at Ankara; subm. by R. D. Barnett, Keeper of the Department of Western Asiatic Antiquities, British Museum. Relevant publications-Mellaart, 1958, 1959. Relevant dates-W-623 Matarrah VI 4, $7570 \pm 250$; W-617 Mersin (basal level), $7950 \pm 250$ (Rubin and Alexander, 1958). Comment: date compares well with the Matarrah date in terms of relative chronology, whereas the Mersin date appears to be far too low. Pretreatment: charcoal was very soft and tended to go into solution in $1 \%$ caustic soda. Pretreatment consisted of the usual extraction with hydrochloric acid, but the caustic soda treatment was discontinued after several extractions showed that the sample was in danger of disappearing completely.

\section{CHECK SAMPLE}

\section{BM-59. Nabu Temple, Nimrud, Iraq}

$2400 \pm 150$

Charred wood from the ante-cella of the Nabu Temple at ancient Nimrud on the $\mathrm{E}$ bank of the Tigris, $22 \mathrm{mi} \mathrm{S}$ of modern Mosul $\left(36^{\circ} 11^{\prime} \mathrm{N}\right.$ Lat, $43^{\circ} 20^{\prime}$ E Long), Iraq. Coll. April 1956 by M. E. L. Mallowan, Department of Western Asiatic Archaeology, University of London, and subm. by him for use as a check sample. He states that the actual date of the specimen is almost certainly some decades before 612 в.c., the date when the Nabu Temple was sacked and burnt and the roof (of which the sample was part) fell in. Sample has also been dated by the Dublin laboratory (Delaney and McAulay, 1959) at $546 \pm$ 140 B.c.

\section{REFERENCES}

Barker, H., and Mackey, C. J., 1959, British Museum natural radiocarbon measurements I: Am. Jour. Sci. Radioc. Supp., v. 1, p. 81-86.

Delaney, C. F. G., and McAulay, I. R., 1959. Royal Dublin Soc. Sci. Proc., ser. A, v. 1,

Lewis, I. M., in press (a), The so-called Galla Graves of Northern Somaliland: Man. [Rome].

Libby, W. F., 1955, Radiocarbon dating, 2d ed.: Chicago, Univ. Chicago Press, ix, 175 p. Mellaart, James, 1958, Excavations at Hacilar: Anatolian Studies, v. 8, p. 127-156. Studies, v. 9, p. 51-56.

Morgan, Faith de M., and Ashbee, P., 1958, The excavation of two long barrows in Wessex: Antiquity, v. 32, p. 104-111.

Quaritch-Wales, H. G., 1957, An early Buddhist civilisation in Eastern Siam: Jour. Siam Soc., v. 45, pt. 1 [April].

Robinson, K. R., and Cooke, C. K., 1950, Some unusual elements in the Wilton industry in the Matopo area of Southern Rhodesia: South African Archaeol. Bull., v. 5, no. 19. 1954, Excavations at Amadzimba Cave, located in the Matopo Hills, Southern Rhodesia: Southern Rhodesia Nat. Mus. Occ. Papers no. 19.

Rubin, Meyer, and Alexander, Corrinne, 1958, U. S. Geological Survey radiocarbon dates IV: Science, v. 127, p. 1476-1487.

Sankalia, H. D., 1958, Excavations at Maheshwar and Navdatoli: Poona.

Tweedie, M. W. F., 1953, The Stone Age in Malaya: Malayan Branch Royal Asiatic Soc. Jour., v. 2, fig. 34 .

Williams-Hunt, P. D. R., 1952, Recent archaeological excavations in Malaya 1951: Malayan Branch Royal Asociatic Soc. Jour., v. 1, p. 184.

Wright, E. V., and Wright, C. W., 1947, Prehistoric boats from North Ferriby, East Yorkshire: Proc. Prehist. Soc., n.s., v. 13, p. 114-138.

Wymer, John, 1959, Excavations at Thatcham, Berkshire, 1958-interim report: Berkshire Arch. Jour., v. 57.

Vyse, H., 1841, Operations carried on at the Pyramids of Gizeh in 1837: v. 2. 